\title{
研究論交
}

\section{Inorganic Extraction Studies on the System of Some Diphosphonates-nitric Acid}

\author{
Tetrabutyl methylene-diphosphonate and \\ tetrabutyl ethylene-diphosphonate
}

$10 \%$ TBEDP, TBMDP キシレン溶液一硝酸系に扣ける諸元素の分配

By Tomitaro ISHIMORI*, Kan KIMURA*, Eiko NAKAMURA*, Johkun AKATSU* and Toshiko KOBUNE*

\begin{abstract}
A radiochemical study on the solvent extraction behavior of about sixty chemical elements performed in 10\% TBEDP- and 10\%TBMDP-nitric acid systems, respectively. The acidity of the aqueous phase was changed from 1 to $15 \mathrm{~N}$.

The acid dependence curves obtained for each element were very similar between the two systems studied. Considerable regularities were found with respect to the extraction behavior of the corresponding congeners. It was also found that the present results for both systems are fairly similar to those of $100 \% \mathrm{TBP}-\mathrm{HNO}_{3}$ system.
\end{abstract}

\section{INTRODUCTION}

Many organic phosphate esters and phosphine oxides are now known to extract some chemical elements, including tri- $n$-butyl phosphate (TBP) which has been proved to be extractant. The extraction properties of TBP, and some phosphine oxides were systematically surveyed before ${ }^{(1) \sim(4)}$. Following these surveys, organic diphosphonate esters were studied as the extracting agent for inorganic ions.

In the present work, two of the diphosphonates, tetrabutyl methylene-diphosphonate $(T B M D P)^{* *}$ and tetrabutyl ethylene-diphosphonate (TBEDP)** were chosen as the extractant, and the systematic extraction study was carried out radiometrically for about sixty chemical elements, from sodium to neptunium, in $10 \%(\mathrm{v} / \mathrm{v}) \mathrm{TBMDP}$ - and $10 \%(\mathrm{v} / \mathrm{v}) \mathrm{TBEDP}$. nitric acid systems, respectively. These agents have been a little studied by the other investigators already ${ }^{(5)(6)}$.

\section{Experimental}

\section{Reagents}

TBEDP and TBMDP received from the Tama Chem. Co., Tokyo, was used without further purification and diluted to $10 \%$ with xylene, c.p. grade. Nitric acid solutions were prepared by diluting commercial concentrated nitric acid. The acidity was adjusted volumetrically whenever necessary.

\section{Radioisotopes}

The radioactive isotopes used in this experiment were mainly prepared by irradiation of high purity targets in JRR-1**, or JRR-2***

* 石森富太郎, 木村 幹, 中村永子, 吾勝常鶖, 小船 敏子。Chem. Div., Japan Atomic Energy Res. Inst. (日本原子力研究所 化学部)

** Tetrabuthyl ethylene diphosphonate and tetrabuthyl methylene diphosphonate are abbreviated as TBEDP and TBMDP respectively.

** neutron flux: $5 \times 10^{11} \mathrm{n} / \mathrm{sec} \cdot \mathrm{cm}^{2}$

*** neutron flux: $\sim 10^{13} \mathrm{n} / \mathrm{sec} \cdot \mathrm{cm}^{2}$ 
or a linear electron acceralator, JAERI, whereas some of the isotopes were imported from the Oak Ridge National Laboratory, USA and from the Radiochemical Centre, Amersham, UK, or obtained from Radioisotope Production Facilities, JAERI. The checking methods of the radiochemical purity and the specific activity were the same as those reported in the previous papers ${ }^{(1)(7)}$. Table 1 shows the radioisotopes used together with their target materials and remarks. In most cases, familiar chemical forms were chosen as far as possible, and in some cases, the oxidation states and the chemical forms of the tracers were clearly defined, as shown in Table 2. In the case of gold, the ionic species might be chlorocomplex because gold target was dissolved with aqua regia.

Table 1 Sources of radioactive tracers used

\begin{tabular}{|c|c|c|c|}
\hline Element & Tracer & Target & Remarks \\
\hline $\mathrm{Na}$ & ${ }^{24} \mathrm{Na}$ & $\mathrm{Na}_{2} \mathrm{CO}_{3}$ & \\
\hline $\mathrm{Mg}$ & ${ }^{27} \mathrm{Mg}$ & Mg-metal & \\
\hline $\mathrm{Al}$ & ${ }^{28} \mathrm{Al}$ & Al-metal & \\
\hline $\mathrm{P}$ & ${ }^{32} \mathrm{P}$ & & $\begin{array}{l}\text { Production Group, } \\
\text { JAERI }\end{array}$ \\
\hline $\mathrm{S}$ & ${ }^{35} \mathrm{~S}$ & & $\begin{array}{l}\text { Production Group, } \\
\text { JAERI }\end{array}$ \\
\hline $\mathrm{Cl}$ & ${ }^{38} \mathrm{Cl}$ & $\mathrm{NH}_{4} \mathrm{Cl}$ & \\
\hline $\mathrm{K}$ & ${ }^{42} \mathrm{~K}$ & $\mathrm{KNO}_{3}$ & \\
\hline $\mathrm{Ca}$ & ${ }^{45} \mathrm{Ca}$ & & imported \\
\hline $\mathrm{Sc}$ & ${ }^{46} \mathrm{Sc}$ & & imported \\
\hline $\mathrm{Ti}_{\mathrm{i}}$ & ${ }^{51} \mathrm{Ti}$ & Ti hydroxid & \\
\hline $\mathrm{V}$ & ${ }^{52} \mathrm{~V}$ & $\mathrm{NH}_{4} \mathrm{VO}_{3}$ & \\
\hline $\mathrm{Cr}$ & ${ }^{51} \mathrm{Cr}$ & & imported \\
\hline $\mathrm{Mn}$ & ${ }^{56} \mathrm{Mn}$ & $\mathrm{MnO}_{2}$ & \\
\hline $\mathrm{Fe}$ & ${ }^{55,50} \mathrm{Fe}$ & & imported \\
\hline Co & ${ }^{80} \mathrm{Co}$ & & imported \\
\hline $\mathrm{Ni}$ & ${ }^{65} \mathrm{Ni}$ & $\mathrm{Ni}$ sponge & \\
\hline $\mathrm{Cu}$ & ${ }^{64} \mathrm{Cu}$ & $\mathrm{Cu}$ metal & \\
\hline $\mathrm{Zn}$ & ${ }^{65} \mathrm{Zn}$ & & imported \\
\hline $\mathrm{Ga}$ & ${ }^{72} \mathrm{Ga}$ & $\mathrm{Ga}_{2} \mathrm{O}_{3}$ & \\
\hline $\mathrm{Ge}$ & ${ }^{71} \mathrm{Ge}$ & $\mathrm{GeO}_{2}$ & \\
\hline As & ${ }^{76} \mathrm{As}$ & $\mathrm{As}_{2} \mathrm{O}_{3}$ & \\
\hline Se & ${ }^{75} \mathrm{Se}$ & & imported \\
\hline \multicolumn{2}{|c|}{$\mathrm{Br}{ }^{80,80 m} \mathrm{Br}$} & $\mathrm{NH}_{4} \mathrm{Br}$ & \\
\hline $\mathrm{Rb}$ & ${ }^{86} \mathrm{Rb}$ & & imported \\
\hline $\mathrm{Sr}$ & ${ }^{85} \mathrm{Sr}$ & & imported \\
\hline$Y$ & ${ }^{88} Y$ & $\mathrm{Y}_{2} \mathrm{O}_{3}$ & (LINIAC) \\
\hline $\mathrm{Zr}$ & ${ }^{85} \mathrm{Zr}$ & & imported \\
\hline $\mathrm{Nb}$ & ${ }^{85} \mathrm{Nb}$ & & imported \\
\hline Mo & ${ }^{99} \mathrm{Mo}$ & molybdate & \\
\hline $\mathrm{Tc}$ & ${ }^{99} \mathrm{Tc}$ & & imported \\
\hline
\end{tabular}

\begin{tabular}{|c|c|c|c|}
\hline \multicolumn{2}{|c|}{ Element Tracer } & \multirow[t]{2}{*}{ I Target } & \multirow{2}{*}{$\begin{array}{c}\text { Remarks } \\
\text { imported }\end{array}$} \\
\hline $\mathrm{Ru}$ & ${ }^{106} \mathrm{Ru}$ & & \\
\hline $\mathrm{Pd}$ & ${ }^{109} \mathrm{Pd}$ & Pd metal & $\begin{array}{l}{ }^{111} \mathrm{Ag} \text { was removed by } \\
\text { pptn. of } \mathrm{AgCl} \text { after } \\
\text { addition of } \mathrm{Ag} \text { carrier. }\end{array}$ \\
\hline $\mathrm{Ag}$ & ${ }^{110 \mathrm{~m}} \mathrm{Ag}$ & $\mathrm{AgNO}_{3}$ & \\
\hline $\mathrm{Cd}$ & ${ }^{115 m} \mathrm{Cd}$ & & imported \\
\hline In & ${ }^{114 \mathrm{~m}} \mathrm{In}$ & & imported \\
\hline $\mathrm{Sn}$ & ${ }^{113} \mathrm{Sn}$ & & imported \\
\hline $\mathrm{Sb}$ & ${ }^{124} \mathrm{Sb}$ & & imported \\
\hline $\mathrm{Te}$ & \multicolumn{2}{|c|}{${ }^{127,129} \mathrm{Te} \mathrm{TeO}_{2}$} & \\
\hline$I$ & ${ }^{131} I$ & & $\begin{array}{l}\text { Production Group, } \\
\text { JAERI }\end{array}$ \\
\hline $\mathrm{Cs}_{\mathrm{s}}$ & ${ }^{137} \mathrm{Cs}$ & & imported \\
\hline $\mathrm{Ba}$ & ${ }^{139} \mathrm{Ba}$ & \multicolumn{2}{|c|}{$\mathrm{Ba}(\mathrm{OH})_{2} \cdot 2 \mathrm{H}_{2} \mathrm{O}$} \\
\hline $\mathrm{La}$ & ${ }^{140} \mathrm{La}$ & \multicolumn{2}{|c|}{$\mathrm{La}_{2} \mathrm{O}_{3}$} \\
\hline $\mathrm{Ce}$ & ${ }^{144} \mathrm{Ce}$ & & imported \\
\hline $\mathrm{Pm}$ & ${ }^{147} \mathrm{Pm}$ & & imported \\
\hline $\mathrm{Eu}$ & ${ }^{152,154} \mathrm{Eu}$ & & imported \\
\hline $\mathrm{Tb}$ & ${ }^{160} \mathrm{~Tb}$ & \multicolumn{2}{|l|}{$\mathrm{Tb}_{4} \mathrm{O}_{7}$} \\
\hline $\mathrm{Lu}$ & ${ }^{177} \mathrm{Lu}$ & \multicolumn{2}{|l|}{$\mathrm{Lu}_{2} \mathrm{O}_{3}$} \\
\hline $\mathrm{Hf}$ & ${ }^{181} \mathrm{Hf}$ & \multicolumn{2}{|r|}{ imported } \\
\hline $\mathrm{Ta}$ & ${ }^{182} \mathrm{Ta}$ & \multicolumn{2}{|r|}{ imported } \\
\hline W & ${ }^{185} \mathrm{~W}$ & & imported \\
\hline $\operatorname{Re}{ }^{1 t}$ & ${ }^{186,188} \mathrm{Re}$ & \multicolumn{2}{|l|}{ Re metal } \\
\hline Os & ${ }^{101} \mathrm{Os}$ & & \multirow{4}{*}{$\begin{array}{l}\text { imported } \\
{ }^{199} \mathrm{Au} \text { was removed } \\
\end{array}$} \\
\hline $\mathrm{Pt}^{198}$ & ${ }^{3 m}, 197 \mathrm{Pt}$ & Pt metal & \\
\hline $\mathrm{Ir}$ & ${ }^{194} \mathrm{Ir}$ & Ir sponge & \\
\hline $\mathrm{Au}$ & ${ }^{198} \mathrm{Au}$ & \multirow{2}{*}{\multicolumn{2}{|c|}{ Au metal imported }} \\
\hline $\mathrm{Hg}$ & ${ }^{203} \mathrm{Hg}$ & & \\
\hline $\mathrm{Tl}$ & ${ }^{204} \mathrm{Tl}$ & \multicolumn{2}{|r|}{ imported } \\
\hline $\mathrm{Pb}$ & ${ }^{212} \mathrm{~Pb}$ & \multirow{2}{*}{\multicolumn{2}{|c|}{$\begin{array}{l}\text { collected from }{ }^{232} \mathrm{ThO}_{2} \\
\text { separated from } \mathrm{RaD}^{(1)}\end{array}$}} \\
\hline $\mathrm{Bi}$ & ${ }^{210} \mathrm{Bi}$ & & \\
\hline$T h$ & ${ }^{231} \mathrm{Th}$ & $\mathrm{ThO}_{2}$ & $\begin{array}{l}\text { (LINIAC) processed by } \\
\text { TBP-extraction }\end{array}$ \\
\hline $\mathrm{Pa}$ & ${ }^{233} \mathrm{~Pa}$ & $\mathrm{Th}\left(\mathrm{NO}_{3}\right)_{4}$ & $\begin{array}{l}\text { Processed by TBP. } \\
\text { extraction }\end{array}$ \\
\hline $\mathrm{U}$ & ${ }^{237} \mathrm{U}$ & $\mathrm{UO}_{2}$ & $\begin{array}{l}\text { (LINIAC) processed by } \\
\text { TBP-extraction }\end{array}$ \\
\hline $\mathrm{Np}_{\mathrm{p}}$ & ${ }^{239} \mathrm{~Np}$ & \multicolumn{2}{|c|}{$\begin{array}{c}\mathrm{UO}_{2}\left(\mathrm{NO}_{3}\right)_{2} \text { Processed by TBP- } \\
\text { extraction }\end{array}$} \\
\hline
\end{tabular}

Table 2 Chemical treatment of tracers

\begin{tabular}{llc}
\hline $\begin{array}{l}\text { Ele- } \\
\text { ment }\end{array}$ & Treatment & $\begin{array}{l}\text { Oxidation } \\
\text { state } \\
\text { obtained }\end{array}$ \\
\hline $\mathrm{As}$ & $\begin{array}{l}\text { Reduced with ascorbic acid } \\
\text { Oxidized with } \mathrm{KClO}_{3}\end{array}$ & 3 \\
$\mathrm{Se}$ & Warming in $4 \mathrm{~N} \mathrm{hydrochloric} \mathrm{acid}^{-}$ & 5 \\
$\mathrm{Sn}$ & Oxidized with $\mathrm{KClO}_{3}$ & 4 \\
$\mathrm{Sb}$ & Reduced with ascorbic acid & 3 \\
& Oxidized with $\mathrm{KBrO}_{3}$ & 5 \\
$\mathrm{Hg}$ & Heated in concentrated nitric acid & 2 \\
$\mathrm{Tl}$ & Oxidized with $0.1 \mathrm{M}$ ceric ammonium 3 \\
& nitrate
\end{tabular}



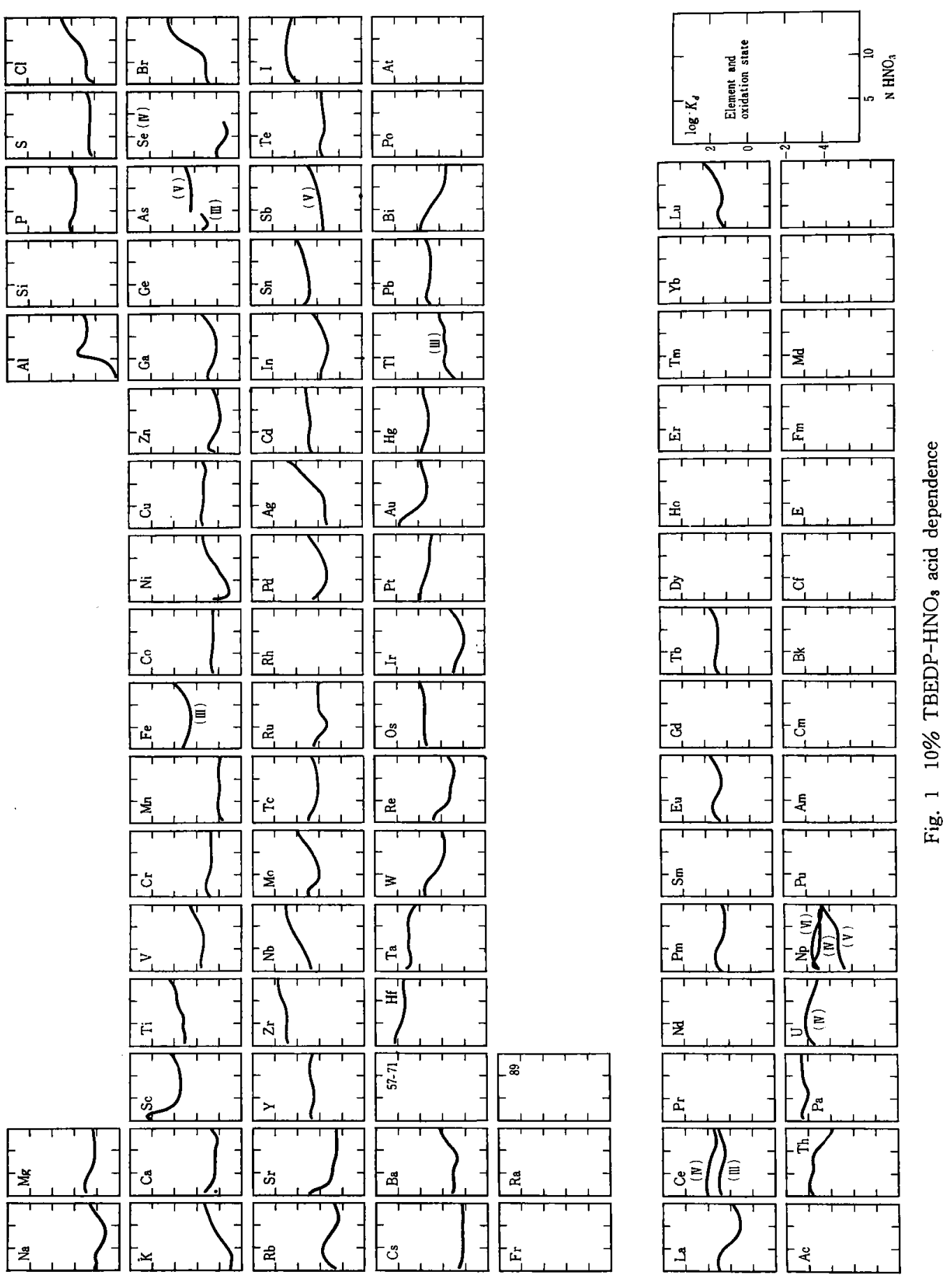

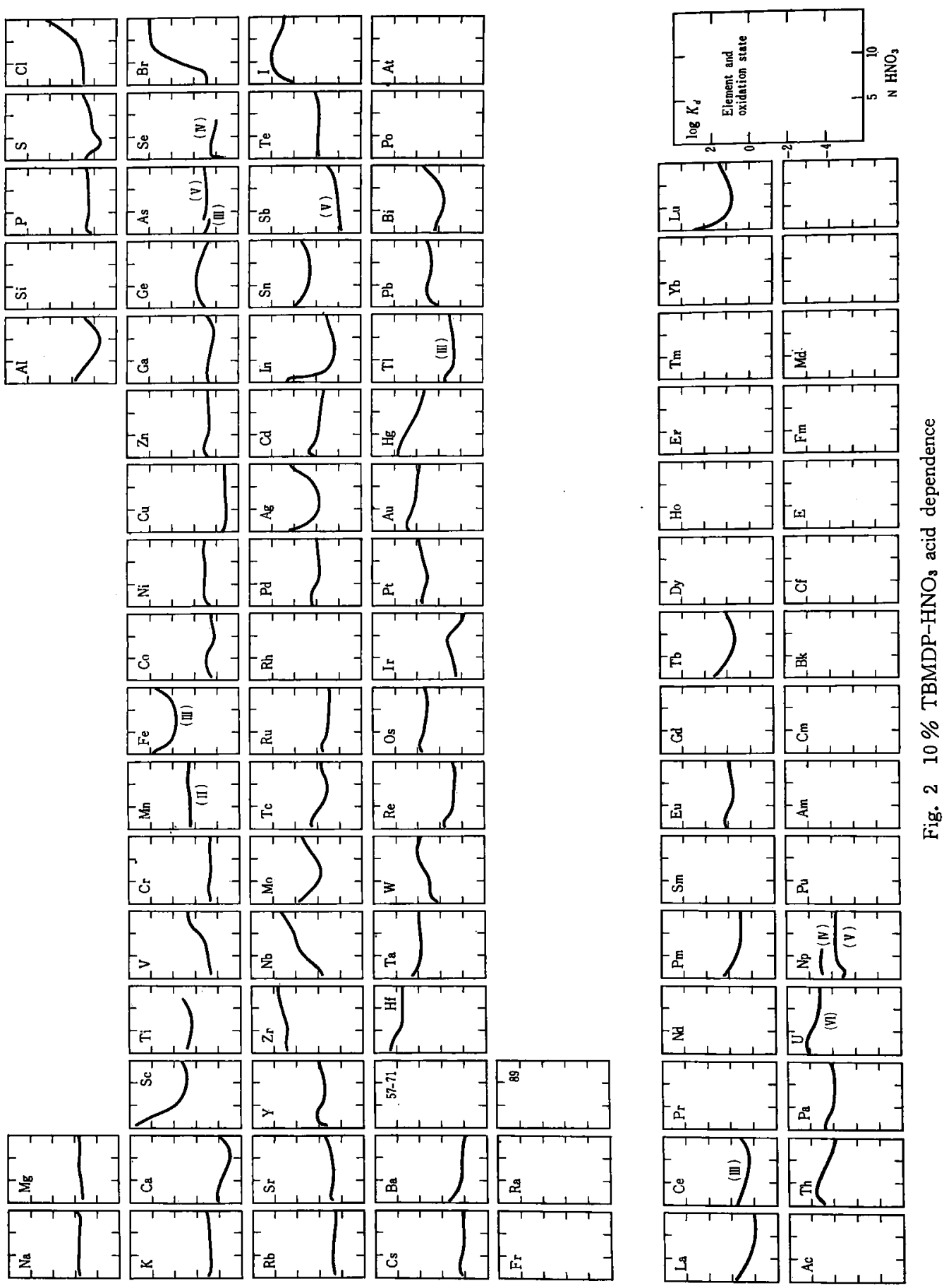


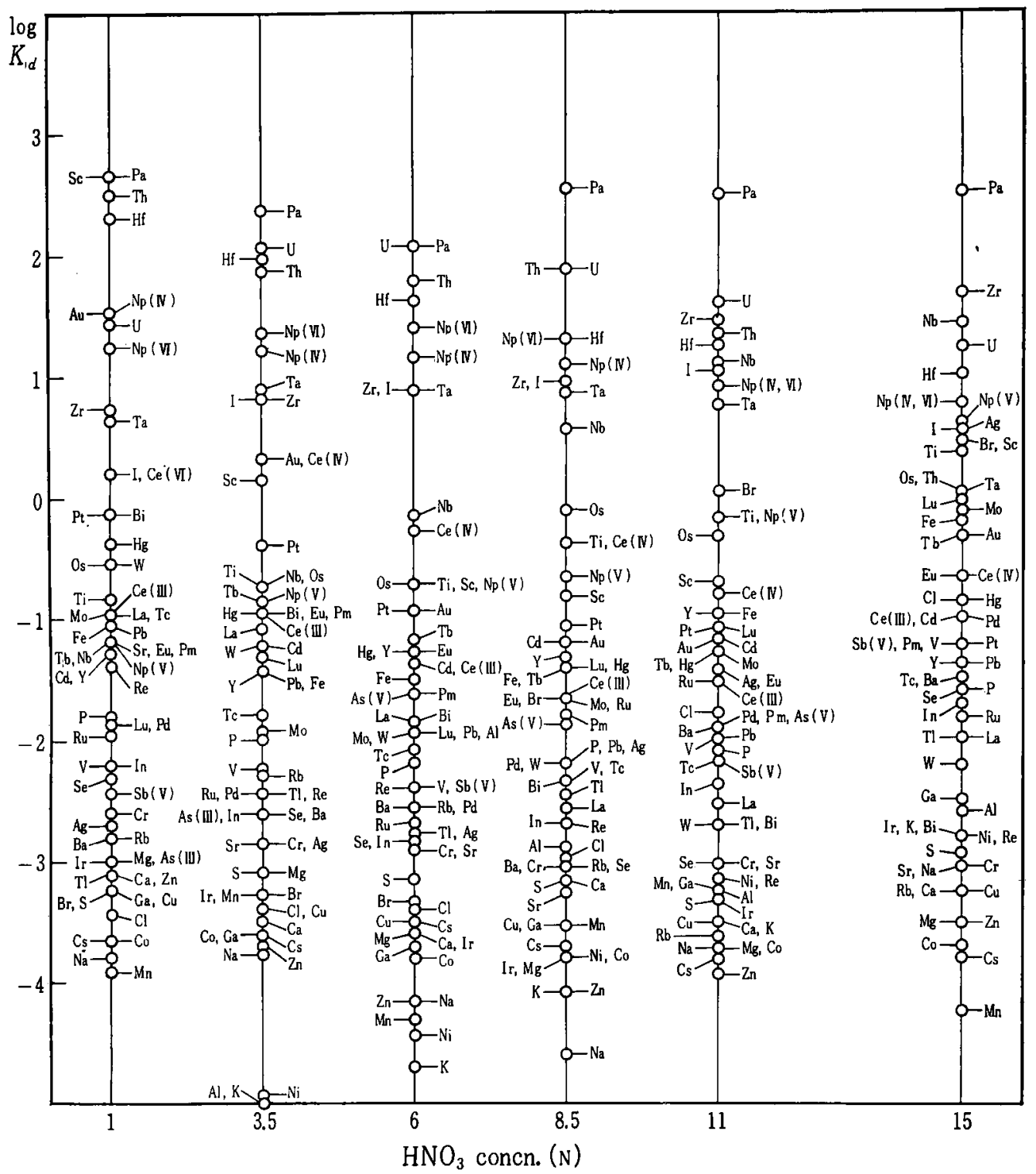

Fig. $3 K_{d}$ values in $10 \%$ TBEDP- $\mathrm{HNO}_{3}$

\begin{tabular}{llc}
\hline $\begin{array}{l}\text { Ele- } \\
\text { ment }\end{array}$ & Treatment & $\begin{array}{l}\text { Oxidation } \\
\text { state } \\
\text { obtained }\end{array}$ \\
\hline $\mathrm{Ce} \quad \begin{array}{l}\text { Reduced with hydroxylamine } \\
\text { Oxidized with } 0.1 \mathrm{M} \text { ceric ammonium }\end{array}$ & 3 \\
nitrate & & \\
$\mathrm{Np}$ & $\begin{array}{l}\text { Reduced with hydroquinone and KI } \\
\text { Eliminating } \mathrm{Np}^{+4} \text { and } \mathrm{Np}^{+6} \text { with }\end{array}$ \\
& 5 \\
\hline
\end{tabular}

\section{Determination of $K_{d}$ values}

The distribution ratios were determined radiometrically changing nitric acid concentration $^{(8)(9)}$.

A portion of organic solution was contacted with the equal volume of acid solution containing the radioisotopes, after being preequilibrated with barren acid solution. The resultant organic or aqueous solution was sometimes scrubbed with fresh acid or organic solution, respectively, in order to obtain the exact distribution ratios. 


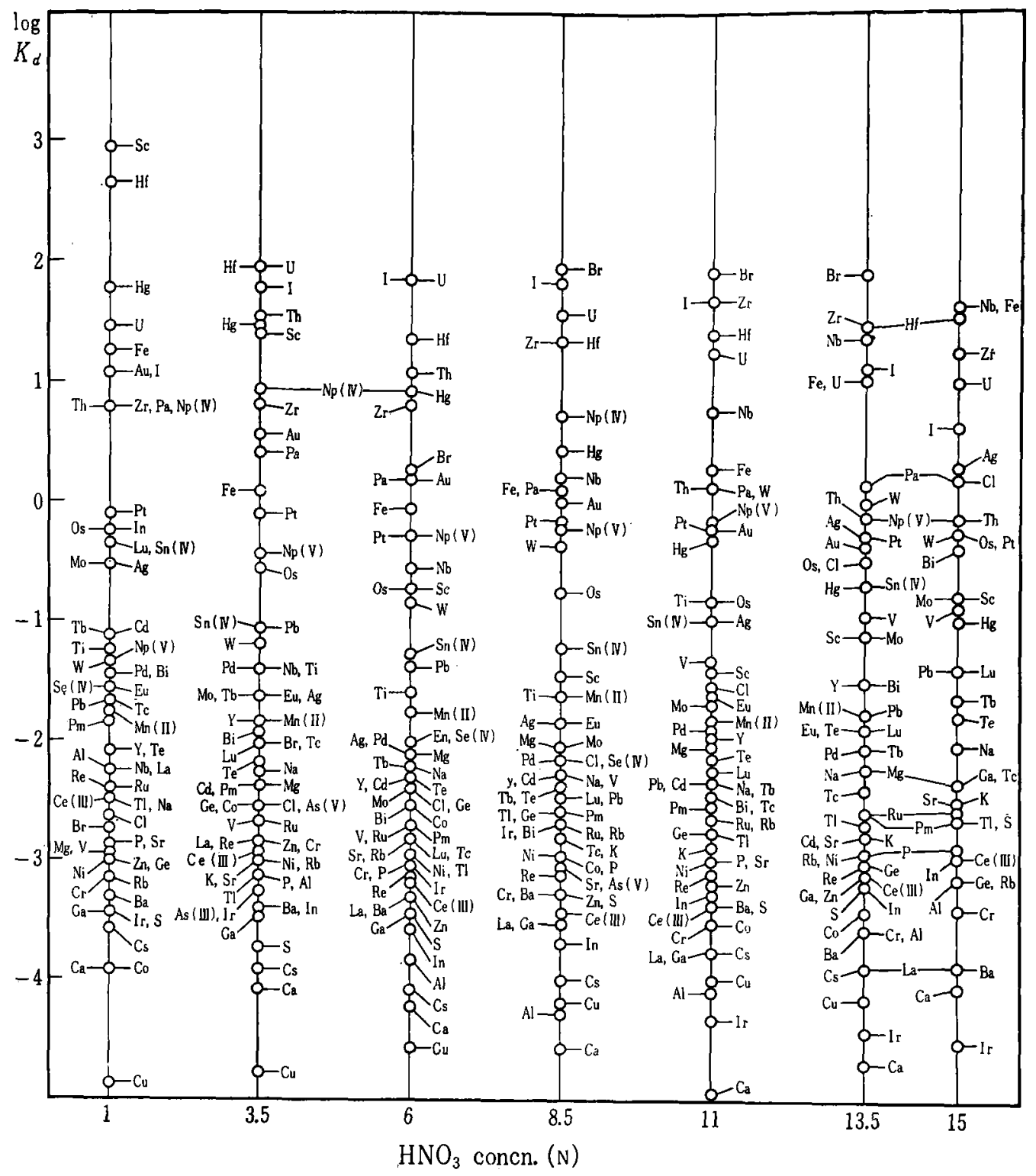

Fig. $4 K_{d}$ values in $10 \%$ TBMDP-HNO

\section{Results and Discussion}

Figs. 1 and 2 represent the acid dependence curves of distribution ratios in the systems of TBEDP- and TBMDP-HNO${ }_{3}$, respectively, as a series of graphs of $\log K_{d}$ vs. $\mathrm{NHNO}_{3}$, where $K_{d}$ is the distribution ratio and $\mathrm{N}$ the normality.

As are seen in Figs. 1 and $2, K_{d}$ values for many elements are generally low, and the acid dependence curve for each element in the system of TBMDP- $\mathrm{HNO}_{3}$ is very similar to that of TBEDP- $\mathrm{HNO}_{3}$ system.

None of alkali and alkaline earth metal ions are extractable at all in the whole acidity range studied.

Acid dependence curves for lanthanide elements are generally low, however, as are seen in Figs. 1 and 2, $K_{a}$ values increase gra- 
dually with increasing atomic number.

$K_{d}$ values for scandium, yttrium and lanthanum decrease with increasing atomic number, so scandium has very high $K_{d}$ values $\left(\sim 10^{3}\right)$ in $\sim 3 \mathrm{~N} \mathrm{HNO}_{3}$ media.

On the contrary to these elements, $K_{d}$ values increase remarkably or little by little with increasing atomic number in some other series, like titanium, zirconium and hafnium; vanadium, niobium and tantalum; or halogen ions. This tendency is also seen in the series of copper, silver and gold, or of zinc, cadmium and mercury. For example, titanium, zirconium and hafnium give $K_{d}$ values of $2 \times 10^{-1}$, 7 and $9 \times 10$ at $3.5 \mathrm{~N}$ nitric acid respectively, in TBEDP- $\mathrm{HNO}_{3}$ system. This results show also that hafnium is one of the most extractable element in both systems studied.

Both thorium and uranium are extracted well from $\sim 11 \mathrm{~N}$ nitric acid solution. $\mathrm{Np}(\mathbb{N})$ and $(\pi)$ is also extractable, however, the $K_{d}$ values are somewhat small comparing with those of the above two elements.

The distribution ratios for protactinium are remarkably low in TBMDP- $\mathrm{HNO}_{3}$ system compared to those for other actinide elements studied. In the system of TBEDP. $\mathrm{HNO}_{3}$, actinide elements including protactinium gives always high $K_{d}$ values.

The $K_{d}$ values for many elements change little with varing the acidity in the systems studied. Those values of tantalum give typical examples as are given in Figs. 1 and 2.

The strong similarity was observed between the two systems studied and $100 \%$ TBP- $\mathrm{HNO}_{3}$ system $^{(2)}$. For example scandium, zirconium, hafnium, niobium, gold and actinide elements are extractable in both systems. Especially, uranium shows almost the same behavior in $100 \% \mathrm{TBP}$ and $10 \%$ TBEDP. $\mathrm{HNO}_{3}$ systems.

Appreciable difference between the extraction behavior in the two systems and 100\% TBP- $\mathrm{HNO}_{3}$ system are observed in the acid dependence curves of several elements, above all, scandium and hafnium, which show high $K_{d}$ values in the low acidity region in TBEDP. and $\mathrm{TBMDP}_{-} \mathrm{HNO}_{3}$ system, and in high acidity region in TBP. $\mathrm{HNO}_{3}$ system.

Figs. 3 and 4 show precise $K_{d}$ values in $10 \%$ TBEDP- and 10\% TBMDP- $\mathrm{HNO}_{3}$ systems.

\section{(Received February 11, 1963)

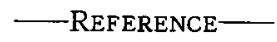

(1) T. Ishimori, K. Watanabe, E. NAKAmura: Bull. Chem. Soc. Japan, 33, 636 (1960).

(2) T. IsHIMORI, K. WATANABE: ibid., 33, 1443 (1960).

(3) T. Ishimori, K. Watanabe, T. Fujino: This Journal, 3, No. 1, 19 (1961).

(4) T. Ishimori, K. Kimura, T. Fujino, H. Murakami: ibid., 4, No. 2, 117 (1962).

(5) T. V. Hearly, J. KenNedY: J. Inorg. Nucl. Chem., 10, 128 (1959).

(6) H. SAISHO: Bull. Chem. Soc. Japan, 34, No. 6, 859 (1961); 34, No. 9, 1254 (1961).

(7) T. Ishimori, K. WATANABE, K. KimURA: This Journal, 2, No. 12, 750 757 (1960).

(8) K. Kimura: Bull. Chem. Soc. Japan, 33, 1038 (1960).

(9) T. IshimorI, E. NAKAMURA: ibid., 32, 713 (1959).

(ii) E. NaKamuRa: Radiochimca Acta, 2, 66 (1963).

(11) E. AKatsu, T. Kuroyanagi, T. Ishimori:

To be published. 